\title{
Lutas negras no largo da Banana'
}

Renata Monteiro Siqueira* https://orcid.org/0000-0001-9537-2795

Introdução

Ao se abordarem a história e a memória da população negra da Barra Funda, em São Paulo, são, sobretudo, suas contribuições culturais que vêm à tona. Lá teriam surgido os primeiros cordões carnavalescos negros da cidade, a começar pelo Grupo Barra Funda, ou Camisa Verde, em 1914 (Britto, 1986; Simson, 2007). O samba permeava o cotidiano das ruas, porões e botequins (Silva, 1990), compondo as "sonoridades paulistanas" (Moraes, 1997). O largo da Banana, nas imediações da estação de trem (Figura 1), onde convergiam a informalidade urbana, econômica e das práticas culturais, foi alçado a locus par excellence da sociabilidade negra dita "espontânea". Esses elementos contribuíram para que o bairro fosse incorporado ao "território mais caracterizadamente negro de São Paulo" no início do século XX (Rolnik, 2003, p. 77).

1. Este artigo decorre de reflexões iniciadas em 2019, durante um estágio de pesquisa na Universidade de Illinois, com apoio da Fapesp (Processo n. 2016/26239-8), supervisionado pelo professor Marc Hertzman, a quem agradeço profundamente o acolhimento e a interlocução generosa. Agradeço a Karen Freire, Stella Paterniani, Cassandra Osei, Paulo Martins, Juan Suarez e Marcelo Kuyumjian e, muito especialmente, ao Rafael Cesar, pelas leituras atentas e discussões proveitosas. Ao Bruno Santos pela edição da Figura 1. 


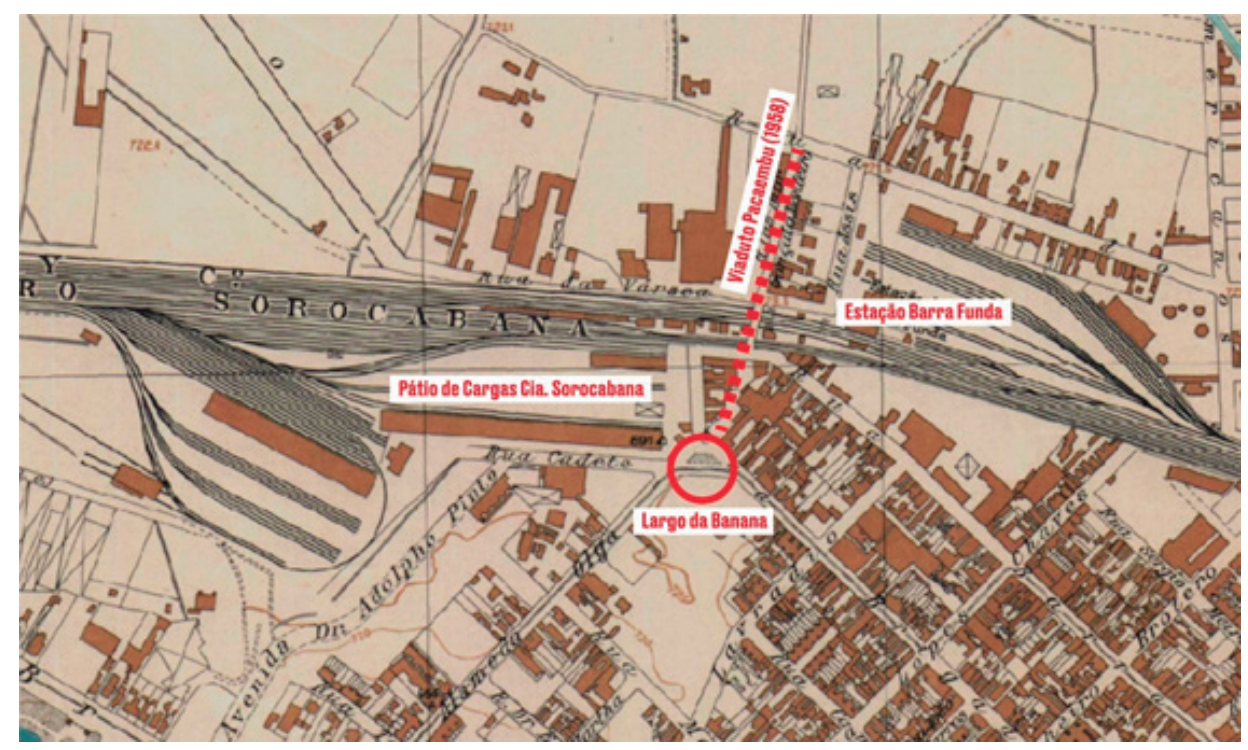

Figura 1: Localização do largo da Banana sobre o Mapa Topográfico Sara Brasil (1930).

Com a noção de "território negro", Raquel Rolnik estimulou, nos anos 1980, um debate um tanto inédito em seu campo de estudos, ao menos em São Paulo. Produtos da "segregação racial, discriminação e dominação brancas", tais territórios eram marcados pelas "estigmatização e marginalização" e pela "construção de singularidade e elaboração de um repertório comum” ([1989] $]^{2} 2007$, pp. 75-6). Para conhecer suas especificidades, a autora convocou uma aproximação entre urbanistas e cientistas sociais. Ieda Britto, Olga Von Simson e José Carlos Gomes da Silva, antropólogos, e Rolnik, arquiteta e urbanista, dialogaram direta e indiretamente e convergiram em seus pressupostos e conclusões. O largo da Banana, "berço do samba" e "território dos negros valentões", teria abrigado, segundo as análises, uma resistência cultural informal, segregada e na contramão do processo de modernização, durante a Primeira República (Britto, 1986, p. 39; Silva, 1990, p. 56; Butler, 1998, p. 75; Rolnik, 2003, p. 76).

Beneficiando-me de problematizações recentes em torno da categoria “território negro" (Silva, 2018; Paterniani, 2019), sugiro que o largo da Banana abrigou lutas negras mais plurais, mais duradouras e menos insulares. Nas próximas duas seções, discuto o processo de legitimação do samba paulista a partir dos anos 1970. Inicialmente, analiso a produção da Coleção Carnaval Paulistano no Museu da Imagem e do Som de São Paulo, MIS-SP. Essa instituição foi um lugar privilegiado de interlo-

2. A data entre colchetes refere-se à edição original da obra. Ela é indicada na primeira vez em que a obra é citada. Nas demais, indica-se somente a edição utilizada pelo autor (N. E.). 
cução entre artistas, pesquisadores e críticos interessados, por razões nem sempre convergentes, em afirmar uma tradição paulista autêntica e autônoma em relação ao samba e carnaval do Rio de Janeiro (Fernandes, 2018). Em seguida, em diálogo com autores que mobilizaram esse acervo, inquiro os termos que permitiram condensar a representação singular, segregada e pretérita do largo da Banana. Argumento que tal leitura decorreu da cisão analítica entre resistência cultural negra e política de integração social, direcionando expectativas de raça e classe (Hertzman, 2013; Domingues, 2019).

$\mathrm{Na}$ sequência, exploro entrevistas realizadas com dois artistas negros considerados "testemunhas oculares" da origem do samba e do carnaval paulistanos. Dionísio Barbosa (1891-1977), um dos fundadores do Grupo Barra Funda, era o "patriarca” de uma família numerosa e do carnaval de São Paulo (Simson apud Barbosa, 1976, 7’26”). José Narciso Nazaré, ou Zezinho da Casa Verde (1910-1988), ensacou café no pátio da Barra Funda, aproximando-se, em tese, do "autêntico" sambista de rua. Sem duvidar do papel pioneiro dos "negros valentes do largo da Banana", os entrevistadores buscaram elucidar aspectos internos às práticas culturais. Na quarta seção, afastando-me desses objetivos, busco, nos diálogos, elementos que, laterais aos interesses da equipe, eram centrais para como os dois homens negros significaram sua história. À luz de relatos sobre suas escolhas profissionais, aspirações por prestígio e respeitabilidade e estratégias de enfrentamento da discriminação racial, exploro, na seção seguinte, as disputas discursivas em torno do "berço" do samba. Os registros que serviram à legitimação de sua história remota e esvaída permitem, assim, outras escutas. Os depoimentos dos carnavalescos testemunham o cotidiano de trabalho incerto e precário no pátio ferroviário, prolongando-se muito além da Primeira República. As variadas estratégias de enfrentamento dessas adversidades, no entanto, contradizem que aquele fosse um território segregado onde negros pobres resistiam inconscientes e arredios ao mundo que os rodeava.

\section{Berço do samba}

Em janeiro de 2020, a prefeitura de São Paulo afixou uma placa em "homenagem ao samba no antigo largo da Banana” (Simões, 2020) nos baixos do viaduto Pacaembu. A maioria dos presentes integrava os circuitos do carnaval paulistano, com destaque para a escola de samba Mocidade Camisa Verde e Branco. A organização, fundada em 1953 na Barra Funda, reivindica, com a homonímia, sua filiação ao cordão de 1914. Durante o evento, representantes do município e do carnaval deram testemunho da importância política daquele gesto. Ele restituía, simbólica e tardiamente, uma memória urbana e cultural negra apagada da cidade e subtraída de seus habitantes. 

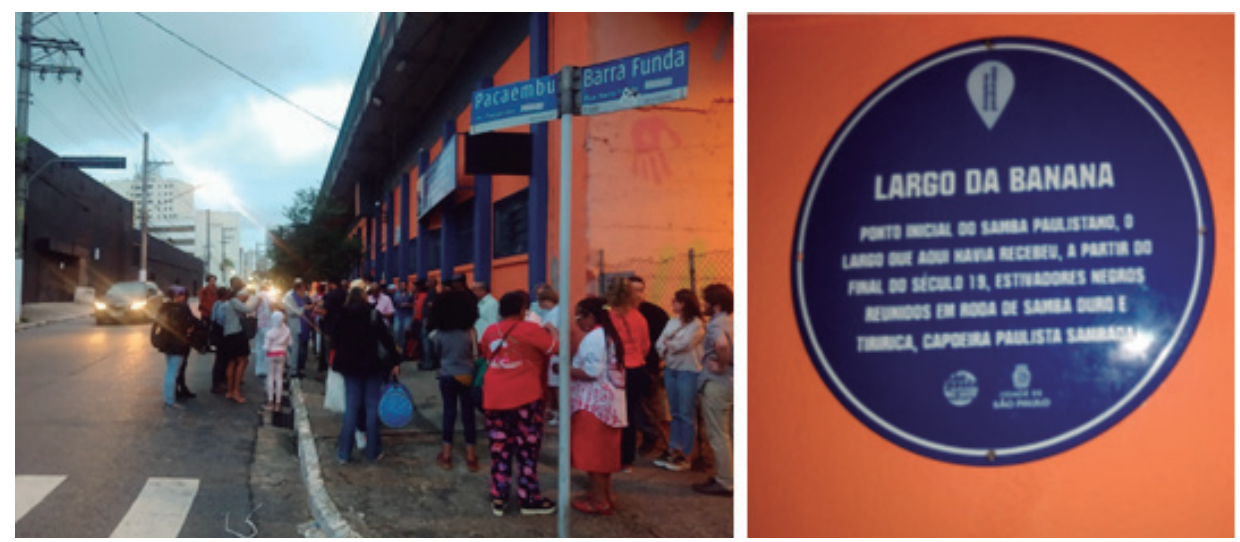

Figura 2: Emplacamento do largo da Banana, 22/01/2020.

Na placa, lê-se: "Largo da Banana: ponto inicial do samba paulistano, o largo que aqui havia recebeu, a partir do final do século XIX, estivadores negros reunidos em roda de samba duro e tiririca, capoeira paulista sambada” (Figura 2). A quantidade de informações é proporcional à lacuna que a frase busca preencher. Poucos ouviram falar do largo da Banana ou conhecem o samba duro e a tiririca. Menos seriam capazes de nomear "estivadores" que trabalharam no pátio de cargas da estação de trem até sua desativação, na década de 1970, para dar passagem à linha oeste-leste do Metrô (Metrô, 1978).

O tributo gravou nas paredes do viaduto alguns dos principais elementos de uma narrativa sobre a identidade e origem do samba de São Paulo, consolidada a partir dos anos 1970. Diferentemente do Rio de Janeiro, onde o gênero musical foi mais cedo "elevado ao grau de identidade universal de uma nação forjada em meio a fissuras reais”, na capital paulista, sua legitimação foi tardia (Fernandes, 2018, p. 28; 275). A Coleção Carnaval Paulistano do MIs-sp foi fundamental nesse processo. Criado em 1970, o museu imbuía-se de um "perfil sociológico e antropológico", ambicionando documentar "manifestações culturais e artísticas, folclóricas e eruditas", em especial de "regiões ou temáticas [...] desconhecidas, ou em vias de desaparecimento" (Lenzi, 2018, pp. 107-8). Sua fundação teve apoio de seu congênere do estado da Guanabara, criado cinco anos antes, com a participação direta de seu diretor, Ricardo Cravo Albin (Idem, p. 269).

Um dos carros-chefes do MIS-RJ era o projeto audiovisual Depoimentospara a posteridade, criado em 1966, por meio do qual seu Conselho Superior de Música Popular Brasileira procederia a uma atualização da identidade do samba carioca, definindo seus agentes históricos (Fernandes, 2018, p. 278). Estava em jogo a reafirmação de uma brasilidade essencial, emanada do Rio de Janeiro, em um passado idealizado. 
Em suma, o sambista legítimo não era profissional, não se apegava a dinheiro, nem era "intelectualizado" (Hertzman, 2013, p. 231). A sequência de negativas sinaliza os estereótipos raciais em operação.

O jornalista José Ramos Tinhorão, membro fundador do conselho de música do MIS-RJ, foi um dos mais influentes defensores dessa visão. Seguidor de uma "cartilha nacionalista marxista", ele identificava a "pureza" dos gêneros musicais e seus autênticos produtores com as "classes dominadas", que não teriam sofrido "as influências deletérias do internacionalismo burguês" (Fernandes, 2018, pp. 225-6). Sua reconhecida autoridade no debate nacional, o interesse em autorizar-se, também, na autenticidade "regional" (Idem, p. 305) e o cerceamento da autonomia do museu fluminense pelo regime militar (Idem, p. 239) devem tê-lo estimulado a participar das primeiras iniciativas da coleção paulistana. Em 1976, ele coordenou a entrevista a Dionísio Barbosa, único registro do MIS-SP com um carnavalesco até 1981.

Assim como no Rio, o MIS-SP também investiu em um projeto de História Oral, que ganhou fôlego na administração de Boris Kossoy, entre 1980 e 1983 . A Coleção Carnaval Paulistano, coordenada por Olga Von Simson, era uma das dezoito áreas desse programa (Lenzi, 2018, p. 184). O acervo decorreu de uma parceria com o Centro de Estudos Rurais e Urbanos da Universidade de São Paulo, Ceru-Usp, onde a antropóloga realizava seu doutorado ${ }^{3}$. O MIS-SP disponibilizou a infraestrutura necessária à sua etnografia do "carnaval negro" (Simson, 2016). Seu método científico contrastava com a informalidade característica dos Depoimentos... do MIS-RJ (Mendonça, 2012, p. 284) e da entrevista de 1976, que Simson também acompanhou. ${ }^{4}$

Simson e os demais cientistas sociais que se lançavam ao estudo do samba e do carnaval paulistanos compartilhavam com os parceiros do MIS-RJ expectativas de raça e classe que definiam os parâmetros da cultura popular tradicional. Um dos objetivos da antropóloga era inventariar e salvaguardar a memória de práticas desaparecidas ou ameaçadas, sobretudo após a oficialização do carnaval, em 1968. Essa teria estimulado uma "visão empresarial", atribuída à crescente presença de brancos, que convertiam o carnaval em "show-mercadoria" (Simson, 2007, p. 233). Isso se refletia na metodologia adotada, priorizando entrevistar os carnavalescos negros “mais idosos”. Na escassez desses representantes, Simson incluiu gerações mais novas

3. A prática de estabelecer parcerias com pesquisadores e centros universitários remonta à fundação do MIS-SP (Lenzi, 2018, p. 182).

4. A gravação da entrevista a Dionísio Barbosa inicia-se com o diálogo já começado. Conversas paralelas se sobrepõem à sua voz, que se torna, por vezes, inaudível. Em diversas ocasiões, Tinhorão o interrompia, passando ele próprio a dar explicações à equipe. Também são evidentes momentos de frustração do entrevistador, que buscava encerrar a conversa, animando-se outra vez quando o músico dizia algo de seu interesse. 
entre os que teriam vivido "todas as fases do carnaval paulistano" (Idem, p. 94), como Geraldo Filme (1927-1995).

Embora a oficialização do carnaval não fosse propriamente uma ruptura (Silva, 2011, p. 140), ela instaurou um debate no meio artístico. Ambivalentes, os músicos deslizavam entre a preocupação com a tradição ameaçada e a aposta otimista de que São Paulo "superaria" o Rio (São Paulo, 1972). Com algo, quase todos concordavam: o largo da Banana não existia mais. Já em 1968, Geraldo Filme lamentou seu fim, quando "o progresso fez do bairro uma cidade" (Souza, 1968). Suas canções e suas parcerias com o dramaturgo Plínio Marcos (Marchezin, 2016) projetaram o largo em primeiro plano, brindando-o com o epíteto de "berço do samba" (Souza, 1971). Os jornais também davam publicidade ao largo da Banana, geralmente durante o reinado de Momo. Segundo as reportagens, lá nascera a festa popular, ainda primitiva e perigosa. Com a consolidação da metrópole moderna, o lugar "do tempo em que samba era coisa pra valente" (Barros, 1977), sujeito a "tiroteios" e evitado por "boas famílias" (Amâncio, 1977), estava fadado ao desaparecimento.

Acadêmicos interessados nos sujeitos, práticas e territórios negros em São Paulo chegaram a conclusões semelhantes. Seus estudos deram lastro científico à interpretação sobre o samba e o carnaval paulistanos que ressoa ainda hoje. Em uma cidade "ainda provinciana" (Britto, 1986, p. 23), carregadores negros, pobres e robustos teriam resistido à opressão por meio da música, da dança, do jogo, da valentia e da recusa total à "ordem dominante" (Idem, p. 39). O samba praticado cotidianamente no largo da Banana, guiado pelos saberes e laços herdados dos ancestrais africanos, teria uma dimensão política "inconsciente" (Silva, 1990, p. 3).

Os pesquisadores desejavam dar a ver formas de existência e resistência negras excluídas da história oficial. Contudo, ao fazê-lo, fixaram os sentidos da negritude dos sujeitos que tornavam visíveis (Scott, 1998, p. 301). O largo da Banana, ocupando o primeiro polo do binário "samba-cidade", desaparecera no decorrer do processo de metropolização, em um momento incerto ou, seguindo a pista de Geraldo Filme, em 1958, com a construção do viaduto Pacaembu (Da Silva, 2018, p. 15). Intriga, portanto, que uma reportagem de 1967 informe que o largo da Banana ainda era um ponto de samba popular (Ferreira, p. 80) e que notícias cotidianas, embora raras, se refiram ao local bastante depois da inauguração do viaduto (Os problemas, 1974).

\section{Negros em um mundo à parte}

Contemporânea ao resgate da memória do carnaval paulistano, consolidava-se a ideia de que expressões culturais como o samba, a macumba, o candomblé e a capoeira "transavam o afronegro" (Gonzalez, 1982, p. 19). Nos anos 1970, a "cultura negra", 
entendida como herança da diáspora africana, ganhou proeminência inédita na agenda antirracista nacional (Pinto, 2013, p. 357). Embora tal interpretação possa parecer atemporal, ela é historicamente constituída (Hertzman, 2013, p. 163; Fernandes, 2014, p. 138). Em todo o país, ao longo do tempo, os negros conceberam sua identidade e sua participação na sociedade de formas variadas (Butler, 1998, p. 13). Em São Paulo, no início do século $\mathrm{xx}$, a experiência social negra foi impactada pela chegada massiva de brancos estrangeiros, sobretudo europeus, fomentada pela política de imigração (Fernandes, 2008, p. 36). Isso colaborou para que parte dos negros rejeitasse a identificação com o continente africano em prol do reconhecimento de sua cidadania como brasileiros (Alberto, 2011, p. 24).

Britto, Silva e Rolnik projetaram no passado uma identidade "afro" coetânea de seus estudos. Os primeiros ativeram-se ao período entre 1900 e 1930. Ensaiando a análise dos territórios negros em um arco temporal maior, Rolnik também encontrou nos anos 1930 um ponto de inflexão. Antes, a ancestralidade africana e as práticas culturais seriam os marcadores primordiais da negritude. Depois, organizaçôes políticas como a Frente Negra Brasileira (1931-1937) e a valorização da mão de obra nacional na era Vargas teriam aberto caminho para a busca por "integração social" (Rolnik, 2007, p. 84).

Rolnik definiu os primeiros territórios negros como "terreiros", loci de sucessivas elaborações e territorializações da cultura africana na diáspora (Sodré, 1988, pp. 15-7). Remontando à sociedade escravista, tais territórios advinham da "afirmação da vontade de solidariedade e autopreservação [...] [que] fundamentava a existência de uma comunidade africana em terras brasileiras" (Rolnik, 2007, p. 76). Os terreiros em que se convertiam os pátios das senzalas perpetuaram-se nos "quilombos urbanos da Primeira República”. Eram "terreiros de samba, de candomblé, de jongo, que [atravessaram] a história dos espaços afro-brasileiros nas cidades” (Idem, p. 77). Nos "clãs africanos urbanos, nos cortiços e casinhas", lugares de culto afro-religioso, macumba e rodas de samba, ter-se-iam originado os primeiros cordões carnavalescos. Tais reflexões integravam sua tese, de grande mérito, sobre a relação orgânica entre legislação e informalidade urbana em São Paulo. Os territórios negros seriam os primeiros a constituir, desde o fim do século XIX, "o vasto campo da ilegalidade ou informalidade urbanística" (Rolnik, 2003, p. 62). Contudo, face ao "modelo europeu" que orientou a política urbana, os "terreiros" desapareceram progressivamente, até que, nos anos 1930, a informalidade urbana seria identificada com o "território estrangeiro" (Idem, p. 60). É relevante que as coordenadas analíticas se transformassem no exato momento em que a "africanidade" dava lugar à "integração".

Essa perspectiva sinaliza o diálogo com a Escola Paulista de Sociologia dos anos 1950 e 1960, também perceptível nos estudos de Silva e de Britto. Os autores endos- 
saram as teses sobre a "herança" da escravidão de que decorreriam o "desajustamento estrutural" e a "anomia" dos negros (Fernandes, 2008; Maio, 1999). Os sambistas do início do século teriam recusado a ordem social estabelecida, "branca e católica”, “porque não quiseram, ou não puderam, adaptar-se”. Assim, o largo da Banana era um "território livre" e um "mundo à parte" (Britto, 1986, p. 39), encerrando sociabilidades que somente caberiam em uma cidade que ainda "se preparava para viver sua primeira transformação estrutural e tornar-se metrópole” (Idem, p. 23).

Silva (1990, p. 2) contrapôs o samba da Barra Funda à organização política do que ele designou, citando Florestan Fernandes, como "elite negra”, organizada em torno da Imprensa Negra. A “elite negra” ocupava posições intermediárias na estrutura de classes, almejando mobilidade social e igualdade entre negros e brancos. Em contrapartida, a Barra Funda fora, no início do século Xx, um "autêntico território negro”, onde residiu uma população recém-migrada das lavouras. Tais indivíduos, "segregados territorialmente e relegados à condição de trabalhadores informais, desenvolveram no bairro ações culturais que confrontavam com o contexto geral da cidade”, experiência essa condensada no largo da Banana (Idem, p. 3; 56-9). Nesses termos, o "território negro" servia à análise das sociabilidades culturais afro "informais" das classes baixas, mas não à ação política “organizada” da "elite negra”. Não se podia, segundo o autor, "tomar como ponto de partida, para a análise da elite negra paulistana um espaço territorial definido da cidade, pois esta não se encontrava em um espaço específico como os trabalhadores informais negros da Barra Funda [...]. Talvez a sua inserção na estrutura de classes [...] tenha contribuído para a própria indefinição territorial do grupo. Esse encontrava-se disperso no espaço urbano ao contrário dos segmentos mais pobres da coletividade negra" (Idem, p. 102, grifos no original). Embora reconhecesse interações entre as "coletividades", Silva privilegiou a separação, por encarnar "experiências diversas do negro enquanto cidadão ou homem público na cidade” (Idem, p. 105). Contudo, os relatos de seu principal informante, Zezinho da Casa Verde, assim como os de Dionísio Barbosa, principal fonte de Britto, sugerem a pertinência de tais aproximações.

Nem "inconscientes", nem "africanos"

Dionísio Barbosa e Zezinho da Casa Verde, que habitaram o dito “território negro" da Barra Funda, valorizaram suas contribuições para o carnaval de São Paulo e narraram suas estratégias para vencer a pobreza e a discriminação racial. Nenhum associou suas práticas à referência “afro". O primeiro rejeitou-a abertamente, sobretudo em relação à religiosidade, e o segundo não abordou a questão. O pai de Dionísio Barbosa vivia em São Paulo antes de mudar-se para o interior “iludido por um fazendeiro”. A 
família retornou de Itirapina à capital do estado na virada do século XIX para o XX (Barbosa, 1976, 80'11'). Dali em diante, Barbosa morou na Barra Funda por toda a vida, exceto quando viajou a trabalho, esporadicamente, para o Rio de Janeiro. Zezinho da Casa Verde nasceu em São Paulo, na rua da Consolação; acompanhando a mãe, mudou-se muitas vezes. Habitaram em moradias coletivas na rua Pamplona e no Bexiga. Por volta de 1921, foram para os Campos Elíseos, na avenida Duque de Caxias. Foi então que ele estreou no Camisa Verde. Depois, fundou e participou de grupos como Flor da Mocidade, Geraldino e Bloco das Caprichosas, esse já na Casa Verde. Antes de fixar-se na margem direita do rio Tietê, nos anos 1930, com esposa, filhos e sogra, morou na rua da Várzea, Barra Funda, e no Bom Retiro. Nos anos 1960, ele fundou a Escola de Samba Morro da Casa Verde.

Ambos destacaram suas experiências profissionais e seus conhecimentos musicais. Dionísio Barbosa aprendeu marcenaria com o pai e teve uma carreira ascendente: foi contratado pela Escola Normal Caetano de Campos, promovido a "auxiliar de trabalhos manuais" e, depois, a "professor de trabalho" (Idem, 60'42”). Segundo ele, todos os integrantes do Camisa Verde "tinham ofício" - eram carpinteiros, ferreiros, pedreiros (Idem, 18'48”). Todavia, "ninguém tocava de ouvido" (Idem, 17’48”). O trabalho não era incompatível com as festas de Momo: "em São Paulo, ninguém nunca perdeu uma segunda-feira por causa de carnaval” (Idem, 47’13”).

Zezinho da Casa Verde começou a trabalhar aos oito anos como ajudante de lustrador (Nazaré, 1981, 7’23”). Frequentou o Liceu de Artes e Ofícios, interrompendo os estudos no segundo ano. Na época, ingressou na Tipografia Siqueira, onde foi pautador e margeador (Idem, 9'18”). Apesar da especialização, ainda que interrompida, o músico desempenhou atividades variadas, entre elas a de ensacador: "Não havia serviço pra trabalhar. E um homem casado tinha que saber fazer tudo [...]. Eu lutei muito com a vida" (Idem, 36'17'). Uma de suas maiores lutas foi profissionalizar-se como músico, com o conjunto Aguias da Meia Noite. Perseguindo a carreira no rádio, precisava, ainda, "trabalhar de dia" para sustentar a família. Os compromissos da banda dificultavam a permanência em empregos estáveis, restando-lhe alternativas informais, como as oferecidas no pátio da Barra Funda (Idem, 55'18”).

A experiência da discriminação racial ordena seu relato. Habilidoso no futebol, ele disputou campeonatos da segunda divisão, "da primeira intermediária [...] e na primeira principal não podia entrar. Eu tenho alguma coisa na minha vida [...], eu tenho um sentimento, eu não podia entrar [...] porque era negro!” (Idem, 242’01”). No rádio, esse sentimento o acompanhou. Em sua primeira audição na Rádio Difusora, em 1935, ele estava “[...] com excesso de nervo. Bom, mas... negro?! Não havia conjunto de negro em São Paulo [no rádio]. Não tinha vez. Na Record não deixavam nós entrar [...], nós fomos [e não nos deixaram] voltar" (Idem, 45’48”). 
Mesmo assim, os artistas acordaram que só abandonariam o grupo no dia em que achassem que haviam "vencido" (Idem, 246'42"). Quando contratados, em outras estações e, finalmente, na Difusora, em 1938, os músicos trabalhavam em condições desiguais. Tocavam de graça, ou por cachê insuficiente. $\mathrm{O}$ dinheiro era reinvestido no próprio grupo: "Nós pusemos na cabeça [...] que aonde o branco fosse de bugue, nós ia de carro. Aonde o branco fosse de traje a rigor nós ia de smoking. E foi isso que fez o conjunto. Porque trabalhava, não recebia um tostão. Aquele dinheiro era todo guardado só pra roupa” (Idem, 4433”).

Aparência e postura eram estratégias fundamentais para o sucesso da banda. Além das roupas elegantes e dos sapatos lustrados, não consumiam álcool nas apresentações. Nas lutas do Águias da Meia Noite, percebe-se o enfrentamento de estigmas que recaíam sobre os negros - o alcoolismo, a irresponsabilidade, a miséria. Para eles, vencer representava o contrário do que a equipe do MIS-SP e os acadêmicos insistiam em reafirmar. Diferente do esperado de um negro "valente", o músico ambicioso empenhou-se em "provar seu valor", uma das definições do termo (Aulete, 1964), performando uma respeitabilidade que aos brancos não era cobrada do mesmo modo.

Uma das frustrações de Zezinho da Casa Verde foi não gravar as composições do conjunto. Intérpretes como Francisco Alves e Orlando Silva os contactaram, mas o grupo manteve firme sua posição: "se o Águias da Meia Noite não podia gravar, ninguém gravava. E foi o que aconteceu” (Nazaré, 1981, 53’10”). Embora considerasse que o conjunto "venceu", tocando em eventos como a estreia da televisão, possivelmente na Argentina (Idem, 260'03”), sobressaía sua indignação: “Sabe por que [não gravamos] ? Porque nós era negro!” (Idem, 260’37”). Nas repetidas vezes em que proferiu a palavra "negro", o músico elevou a voz e suspendeu a fala por alguns instantes. Nessa passagem, podemos escutá-lo bater no próprio corpo. O sentimento transmitido pelo timbre da voz e pelo gesto que não vemos, mas ouvimos, era o de que a cor de sua pele, independentemente do quanto lutasse - "lutei, lutei, lutei, lutei, lutei, lutei" (Idem, 53'47”) - impediu-o de realizar as aspirações para as quais se sentia plenamente capaz.

Mesmo em desvantagem, a banda perseverou. Os músicos tocaram de graça, mas ganharam visibilidade, "enaltecendo o nome do conjunto" (Idem, 44’15”). Isso resultou na oportunidade de viajar à Argentina e de lá, para outros países, por uma temporada, em 1946 (Figura 3) - “Tirando proveito de nós, eles deram nome pra nós” (Idem, 48'56”). No exterior, o artista fez “tudo o que no Brasil não podia fazer. Gravei, filmei” (Idem, 53’50”). Dessa experiência emerge sua grande realização, em termos financeiros, de projetos executados e de reconhecimento. Às conquistas profissionais, somavam-se novas vivências urbanas: "Lá fora fomos conhecer escada rolante [...], esse negócio de andar por debaixo da terra, lá fora eu conheci tudo! 


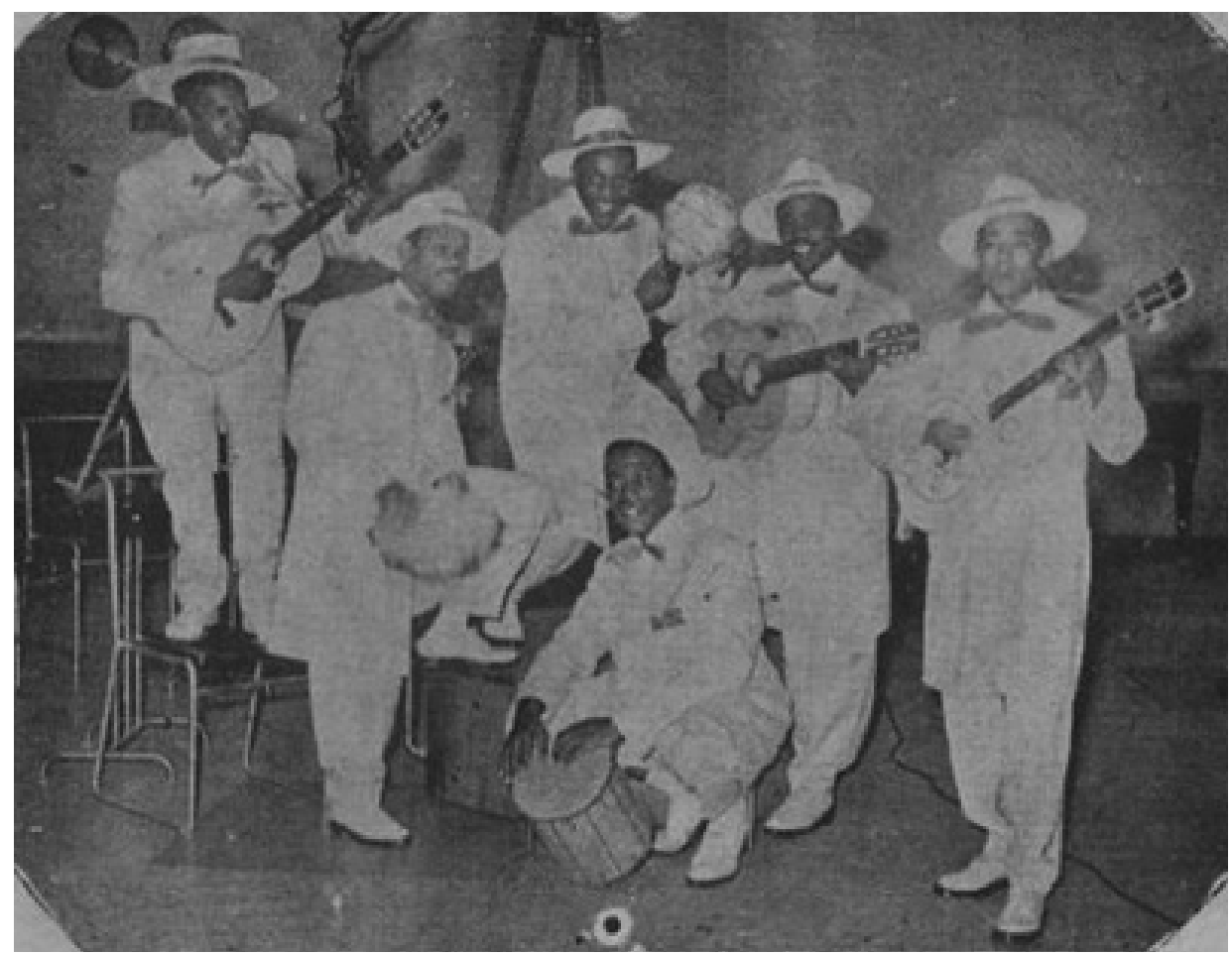

Figura 3: Foto tirada na Rádio El Mundo Buenos Aires em 1946. Zezinho da Casa Verde na ponta, à direita. Fonte: MIS-SP (1981).

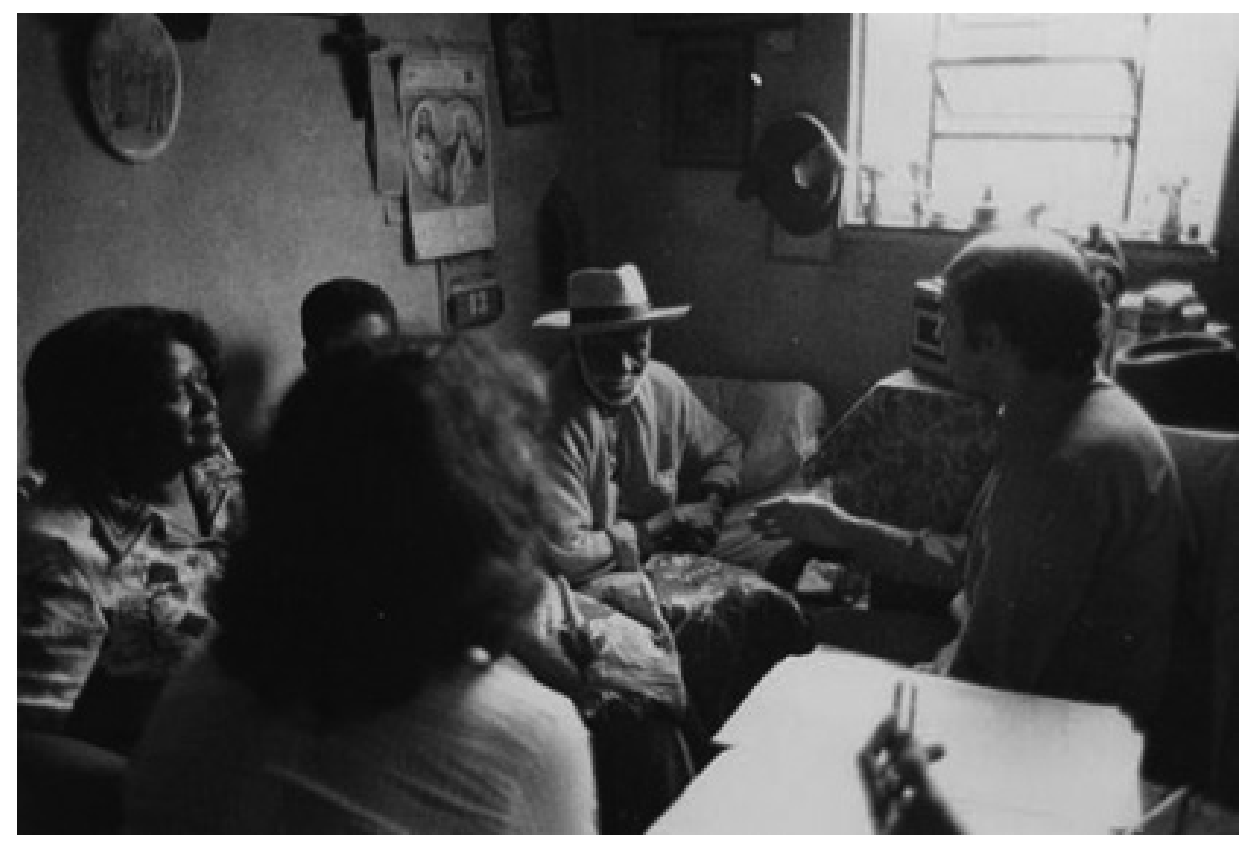

Figura 4: Dionísio Barbosa, em sua residência, entrevistado por José Ramos Tinhorão e equipe. Fonte: MIs-sp (1976). 
Porque aqui eu não conhecia nada" (Idem, 259'53”). Descrevendo suas vitórias no exterior, o sambista denunciava as exclusões experimentadas em sua terra natal. Não é que ele, negro, músico de rádio, sambista de rua, carnavalesco, ensacador, jogador de futebol e tipógrafo não ambicionasse usufruir tudo de "moderno" que o rodeava. Seu acesso era limitado porque ele era "negro!".

A voz de Dionísio Barbosa também acusa um sentimento ao discorrer sobre discriminação racial (Barbosa, 1976, 55’24”). O estatuto do Camisa Verde proibia a participação de brancos em resposta à exclusão de negros em times de futebol (Idem, 53'32”). Em uma partida entre times de negros contra brancos, um atleta recusou-se a jogar pela seleção negra "porque se julgava branco". No entanto, "nos meios paulistanos, ele não entrava” (Idem, 59’01”). Tinhorão sintetizou: “Lá, ele era preto!”. Para Barbosa, o preconceito igualava os "pretos" de todos os tons de pele, impedindo-os de circularem livremente pelos "meios" da cidade que habitavam. Essa posição o aproximava de jornalistas negros paulistas que lhe eram contemporâneos (Alberto, 2011). E, de fato, o carnavalesco foi também jornalista. Em 1923, criou o periódico Nosso Jornal (Gentes, 1933). Em 1933, integrou a comissão organizadora de uma encorpada publicação, resultado de um "esforço-uno-complexivo" de militantes negros das mais variadas "correntes" e sem visar "partidarismos" (Apresentando, 1933). Nela, assinou um texto negando que o baile fosse fator de degradação moral, encorajando os negros a participarem das sociedades dançantes "familiares" (Barbosa, 1933). Dionísio Barbosa era católico (Figura 4) e ia à festa de Bom Jesus de Pirapora “por devoção” (Barbosa, 1976, 30'53”). Ser homem, negro, carnavalesco, jornalista, marceneiro, professor e católico constituíam, todos, sua identidade.

Com algo Dionísio Barbosa não se identificava: com a "África”, sobretudo no que tangia ao fundamento religioso. Questionado sobre um possível nexo entre o toque do bumbo e o jongo, o músico respondeu que "nunca quis saber" de jongo porque era "muito católico" (Babosa, 1976, 76’40”). Apesar da relevância de seu depoimento para a documentação do samba e carnaval paulistanos negros, Dionísio Barbosa foi considerado como alguém que aderiu "aos valores do mundo branco" (Britto, 1986, p. 101). Suas contribuições para o debate antirracista de sua geração foram obliteradas e sua percepção sobre a "cultura negra” foi relativizada e traduzida para encaixar-se na narrativa estabelecida de antemão.

\section{0 berço do samba em disputa}

Os discursos sobre o largo da Banana iluminam a delicada negociação do estereótipo que enquadrava seus sambistas. A equipe do MIS-SP buscava vestígios da figura que, no samba paulista, desempenharia um papel homólogo, mas "singular", ao do 
"malandro" carioca. ${ }^{5}$ Para os entrevistadores, brancos e extrínsecos àquela história, o "negro valente" foi romantizado como herói de uma saga de resistência contra a opressão. Para os músicos negros, o estigma era cotidianamente encarnado em suas experiências e foi cuidadosamente afastado. Os relatos de Dionísio Barbosa e Zezinho da Casa Verde diferiram significativamente, em função do quanto podiam distanciar-se daquele território e dos rendimentos que a narrativa em construção lhes aportava.

Dionísio Barbosa, em sua carreira profissional ascendente, galgou uma posição social que lhe permitia falar "de fora" do largo da Banana e colocar-se "acima" de seus ocupantes na hierarquia social. Ao mesmo tempo, a escola de samba que então lhe atribuía a paternidade e rendia homenagens obtinha os melhores resultados nos carnavais paulistanos ${ }^{6}$. Com o prestígio conquistado e a possibilidade de narrar o largo da Banana em terceira pessoa, reconhecê-lo como "berço" do samba dava força à sua reivindicação de que "o carnaval [de rua] de São Paulo nasceu na Barra Funda! Não nasceu em São Paulo!" (Barbosa, 1976, 9'56”). O mesmo não se pode dizer de Zezinho da Casa Verde, que, perseguindo sucesso como músico profissional, abdicou de ocupações mais estáveis e com melhor retorno financeiro. Embora dominasse ofícios mais especializados, o trabalho de ensacador o colocou inarredavelmente “dentro" do largo da Banana. À época da entrevista, o músico presidia uma escola de samba menor e afastada da Barra Funda. O lugar que lhe reservava o "berço" em construção seria, no máximo, o de autêntico sambista de rua, o que parecia não fazer inteiramente jus ao reconhecimento que almejava para si.

Dionísio Barbosa não se referiu ao "largo da Banana", designação essa que partiu dos entrevistadores. Entretanto, o músico referendou a existência pretérita de um samba feito por negros ensacadores de café na Barra Funda. Embora o carnavalesco não se identificasse com esse grupo, incentivado pelos interlocutores, discorreu sobre eles, cantou seus sambas e descreveu seus jogos de rasteira. Ele próprio trocara pernadas nas rodas da Penha, no Rio de Janeiro (Barbosa, 1976, 83'46”). Zezinho da Casa Verde, ao contrário, negou, por iniciativa própria, que o largo da Banana fosse lugar de samba. Diante disso, o silêncio dos entrevistadores, contrastante com a fala excessiva dos interlocutores de Barbosa, chama a atenção. O músico abordou-o a partir de suas experiências de trabalho, o que se reflete na nomeação: não "largo", mas "pátio" da Banana.

5. Sobre a negociação do estereótipo do malandro no samba carioca, cf. Hertzman (2013).

6. Os entrevistadores, inspecionando os troféus expostos na janela da sala de Dionísio Barbosa (Figura 4), reagiam às datas inscritas - 1974, 1976 - o que interpreto como certa frustração (Barbosa, 1976, 89 '51"). 
Aos dez minutos, Tinhorão perguntou afirmando: "Esse pessoal [do Camisa Verde] que saía direitinho, que ensaiava [...], não se dava com aqueles valentes do largo da Banana, aquilo lá era pessoal da pesada” (Barbosa, 1976, 10'07”). A equipe acreditava que a mesma "turma” morava na alameda Glette e jogava pelo São Geraldo, presumido como time de “várzea” (Idem, 11'27”). Se o entrevistado desviava, Tinhorão retomava, perguntando sobre valentes ainda vivos. A história do próprio Dionísio Barbosa emergia como ruído na lenda dos valentões, que a equipe do MIs-SP parecia incapaz de localizar.

As antecipações dos entrevistadores foram frustradas por sucessivas negativas do carnavalesco. Não havia rivalidade entre o Camisa Verde e o "pessoal da pesada". A “turma de valentes” não jogava pelo São Geraldo. Os negros da Barra Funda não eram todos iguais e isso era preciso "dividir, entendeu?” (Idem, 11'52”).

A certa altura, a equipe conseguiu uma "confirmação" que lhe interessava. Barbosa falou sobre uma tentativa frustrada de formar um time de futebol no Camisa Verde depois que ele deixara o grupo, nos anos 1930. Segundo ele, o fracasso decorria de que "não [tinha] respeito, [nem] uma certa humanidade, [era] gente criada na várzea" (Idem, 56 48”). Extáticos, os entrevistadores reagiram com um longo e uníssono “Aaaaaah!” Tinhorão prosseguiu: “Então confere, o pessoal era mais da pesada mesmo. Era mais [...] gente de várzea e o [grupo] do senhor era um pessoal de mais categoria, que os músicos sabiam música, as moças [...] casavam direitinho” (Idem, 57’15”, grifo meu). Dionísio Barbosa justificou que nunca fora "mais que os outros. Sempre fui negro, humilde, sem nada, pobre, pobre", ao que os entrevistadores condescenderam: “mas tinha noção de respeito [e] de família” (Idem, 57’52”). Construiu-se, assim, uma relativa cumplicidade entre os interlocutores, por meio da qual se foi reforçando a imagem desordeira, ignorante e, seguindo Tinhorão, também promíscua, de uma massa de negras e negros pobres "criados na várzea” da Barra Funda.

Se havia "amizade" entre Dionísio Barbosa e o "pessoal da pesada”, prevaleceram as relações de hierarquia. O carnavalesco afastou-se do estereótipo de "valentões" pelo qual ansiavam os entrevistadores, contrastando-o com sua respeitabilidade. Diferente do marceneiro bem-sucedido, a "turma da pesada” desempenhava um serviço braçal, incerto e mal remunerado (Idem, 19'30”). Os “negros valentes” viviam nos bares el he pediam dinheiro para pinga (Idem, 10'18”). A eles, era vedada a entrada nos bailes de salão do Camisa Verde (Idem, 12'18”). O anfitrião não podia permitir “um açaí, um sururu", pois convidava homens de sobrenome "Rangel Pestana" e "Mesquita" para as apresentações (Idem, 57’34”). A seleção dos convidados para seus eventos "negros" e "familiares", desafiando hierarquias de classe e raça, era parte de esforços, não desprezíveis, visando ao reconhecimento público de seu caráter ordeiro e seu trabalho bem-feito na oficina, na escola, nos bailes e nos palcos (Barbosa, 1976, 
41'43"). Antes de "conferir" que o largo da Banana era lugar de "negros de pinga" (Britto, 1986, p. 39), Dionísio Barbosa trouxe à tona a heterogeneidade e a complexidade das relações entre os negros do bairro.

De "dentro" do largo da Banana, Zezinho da Casa Verde tampouco aderiu ao estereótipo da "turma da pesada”. Suas lembranças do pátio de cargas não eram alegres: "[eu] era o cara mais rude que tinha dentro daquilo ali. Eu aprendi a rir agora depois de velho [...], eu tive dez anos de sacaria em armazém de café. E eu viciei naquilo, homem não pode olhar pro outro, tem que olhar sério [...]. Eu vivi no rádio tanto tempo e não fui comunicativo com ninguém" (Nazaré, 1981, 41'50'). Apresentadas lado a lado, suas experiências no largo da Banana e no rádio eram sérias e silenciosas, contraditórias, em princípio, com a música. Não o eram, contudo, com um mercado de trabalho incerto e competitivo, que então correspondia à parte substancial da economia urbana (Pinto, 1994, p. 110), ou com a hostilidade experimentada em um ambiente pouco receptivo à participação de pessoas negras (Pereira, 2001).

Enquanto carregou saco de café, Zezinho da Casa Verde "bebia como um gambá e ensaiava todo dia [com a banda]!” (Nazaré, 1981, 247’17”). O “[Arthur] Friedenreich da várzea” (Idem, 240’30”) desafiava, no São Geraldo, os times “brancos”, e "não [se contentou]" com o motivo pelo qual the negavam uma oportunidade na primeira divisão. Os elementos pinçados de seu relato para compor a narrativa cultural que o largo da Banana constitui - os negros pobres, os sacos pesados, as relaçóes rudes, a cachaça, o futebol e o samba - passavam longe de uma rejeição do músico à “ordem social”. Essas experiências constituíram a trajetória de um sujeito permanentemente em "luta" para usufruir de direitos formalmente concedidos a todos, mas naturalizados como domínio do "mundo dos brancos".

Zezinho da Casa Verde negou com veemência que no "pátio da Banana” estivesse a origem do samba de São Paulo. Ao contrário, aquele seria o "berço" do samba e do carnaval modernos. Mesmo seu nome era recente: "onde diz hoje pátio da Banana" (Idem, 28'45"). Aquele lugar se tornou, segundo ele, ponto de samba depois da construção do viaduto Pacaembu: "agora o [Mocidade] Camisa Verde [e Branco, de 1953] adotou ali, começou a ensaiar ali, fez aquele viaduto [...], ali sim, mas no passado não tinha pátio da Banana” (Idem, 60’28”). Nazaré associava o “berço tradicional" ao carnaval "moderno" e ao viaduto. O pátio da Banana expressava, nesses termos, aquilo que lamentavam os protetores da tradição cultural negra paulistana, reunidos no MIS-SP. Isso talvez explique por que essa divergência "desapareceu" das análises baseadas nessa entrevista.

Para Zezinho da Casa Verde, o recente pátio da Banana fora, no passado, "lugar de vagabundo, de ficar lá aquele monte de gente o dia lá todo sem fazer nada" (Idem, 60'38”). Tal imagem possivelmente remetia à concentração de outros trabalhadores 
precários, como ele. Tio Mário [Ezequiel] (1927-2019), percussionista do Mocidade Camisa Verde e Branco, trabalhou na sacaria em meados do século Xx. O serviço era acertado diariamente e, quando não havia serviço, eles, literalmente, "ficavam na pedra": "o cara sentado na pedra porque não apareceu nada pra ele fazer hoje, então não tinha, nem comia [...], pegava os restinhos do outro [...]. 'Dá metade aí meu!' - 'Não, eu tô na pedra”' (Ezequiel, 2017, 54’43”). Tio Mário provavelmente discordaria de Zezinho da Casa Verde. Em sua memória do pátio, lá “os caras faziam samba até no bar" (Idem, 54’37”).

Esses relatos apontam a precariedade enfrentada pelos ensacadores na área hoje reconhecida como largo da Banana, bem depois da Primeira República. O que eles não confirmam é que aqueles sujeitos "resistiram” a essa condição, a despeito do mundo ao seu redor. Seus testemunhos indicam inconsistências na interpretação de que aquele fosse um lugar de confraternização de negros marginalizados que nada tinham a oferecer além de seus belos sambas "curtinhos" (Tinhorão apud Barbosa, 1976, 36’08”) e da “venda de sua força física" (Britto, 1986, p. 39).

\section{Considerações finais}

No processo de negociação do samba paulista e de seus símbolos, expectativas de autenticidade do nacional-popular, de identidade e cultura negras confluíram na representação do largo da Banana como seu "berço” resistente. Segregado, desajustado, inconsciente e africanizado, o "território negro" estava fadado ao desaparecimento, antes mesmo de nascer, face à materialização da grande metrópole. Para a equipe do MIS-SP, ser "negro do largo da Banana” correspondia à diferença absoluta. Romantizada pelos pesquisadores, essa perspectiva condenava seus "heróis" à negação e ao passado eternos. Por isso mesmo, não foi assim que Zezinho da Casa Verde e Dionísio Barbosa narraram suas batalhas. Os músicos negociaram os termos de sua representação para a posteridade. Corroborando, dentro de certos limites, as expectativas dos entrevistadores, eles narraram suas lutas para participar da cidade e sociedade "modernas", às quais foram tantas vezes contrapostos. Eles se afastaram de estigmas que reconheciam de longe e que eram imputados aos "valentes pioneiros" do samba paulistano pelos quais sua audiência tanto ansiava.

Seus depoimentos sugerem que "resistência cultural" e "integração social" estavam muito menos dissociadas do que imaginavam seus interlocutores e estudiosos. Os entrevistadores queriam coletar marchas sambadas, mapear agremiações, conhecer sua organização interna, bem como as manifestações “informais” de que bebiam. Enquanto isso, os carnavalescos discorreram bons minutos, ou mesmo horas, sobre assuntos que pareciam frustrar os objetivos das entrevistas. Os mesmos sujeitos que 
trocaram pernadas nas festas da Penha, no Rio de Janeiro, ou nos becos da Barra Funda, em São Paulo, perseguiram sucesso profissional e reconhecimento por sua competência. Dionísio Barbosa insistiu na disciplina com que dirigia seu cordão, que se refletia na qualidade das performances, na rua, nos salóes de baile e no teatro. Para "vencer" no rádio, Zezinho da Casa Verde atravessou territórios pouco convidativos.

Em seus relatos, emergia um cotidiano de que a discriminação racial e estratégias de enfrentamento variadas, individuais ou coletivas, eram constitutivas. Projetando sua respeitabilidade sobre o estigma de que partiam seus interlocutores, Dionísio Barbosa narrou uma história menos irrefletida - ou "primitiva" - que a por eles preconcebida. Do mesmo modo, Zezinho da Casa Verde descreveu seus investimentos como músico e como atleta, não amador, mas profissional. No esforço de se distanciar da imagem de "valente da pesada" que a equipe do MIS-SP colava em seu passado de ensacador e sambista de rua, Zezinho da Casa Verde desmentiu o berço do samba. Salvo engano, sua versão sobre o "pátio da Banana" não suscitou perguntas, nem de entrevistadores, nem de pesquisadores. $\mathrm{O}$ uso que se fez de seu testemunho separou o "sambista de rua" do "músico de rádio", parte essa que acabou obliterada. Dionísio Barbosa, por sua vez, manteve seu posto de "patriarca", mas foi compreendido como alguém que abdicou da própria negritude. Contudo, nenhum desistiu de escolher os termos de suas "lutas", "resistências", "derrotas" ou "vitórias".

\section{Referências bibliográficas}

Alberto, Paulina L. (2011), Terms of inclusion: Black Intellectuals in twentieth-century Brazil. Chapel Hill, University of North Carolina Press.

Amâncio, Moacyr. (1977), "Brincou, dançou”. Folha de S.Paulo, São Paulo, 12/02, p. 29.

“Apresentando...”. (1933), Evolução, 13/05, p.6.

Aulete, F. J. Caldas. (1964). Dicionário contemporâneo da língua portuguesa. Rio de Janeiro, Delta.

Barbosa, Dionísio. "A sociedade boa e a corrompida, do negro em São Paulo". Evolução, 13/05, p. 6.

Barbosa, Dionísio. (1976), Entrevista de Dionisio Barbosa (partes 1 a 5). [Concedida a José Ramos Tinhorão]. Documento Audiovisual. In: Coleção Carnaval Paulistano. São Paulo, Cemis, http://acervo.mis-sp.org.br/, consultado em 10/11/2020.

BArros, Plínio Marcos de. (1977), "Vi o início e não quero ver o fim”. Folha de S.Paulo, 30/05, p. 23.

Britto, Iêda Marques. (1986), Samba na cidade de São Paulo (1900-1930): um exercício de resistência cultural. São Paulo, FFLCH-USP. 
Butler, Kim. (1998), Freedoms given, freedoms won: Afro-Brazilians in post-abolition São Paulo and Salvador. New Brunswick, Rutgers University Press.

Da Silva, Marcelo Vitale T. (2018), Territórios negros em trânsito: Penha de França: sociabilidades e redes negras na São Paulo do pós-abolição. São Paulo, dissertação de mestrado, Faculdade de Filosofia, Letras e Ciências Humanas da Universidade de São Paulo.

Domingues, Petrônio. (2019), Protagonismo negro em São Paulo: história e historiografia. São Paulo, Edições Sesc.

Ezequiel, Mário. Entrevista a Filipe Amado. Audiovisual. Arquivo pessoal do autor, 2017.

Fernandes, Dimitri Cerboncini. (jun. 2014), “A negra essencialização do samba”. Luso-Brazilian Review, 1 (51): 132-156.

Fernandes, Dimitri Cerboncini. (2018), Sentinelas da tradição: a constituição da autenticidade no samba e no choro. São Paulo, Edusp.

Fernandes, Florestan. (2008), A integração do negro na sociedade de classes (O legado da "raça branca”), volume I. São Paulo, Globo.

Ferreira, José Felix. (jun. 1967), “São Paulo também tem samba”. A Cigarra, 6 (53): 76-80.

"Gentes e fatos de outra época”. (1933), A Voz da Raça, 01/04, p. 4.

GonZalez, Lélia. (1982), “O Movimento Negro na última década”. In: Gonzalez, Lélia \& Hasenbalg, Carlos. Lugar de negro. Rio de Janeiro, Marco Zero, pp. 9-66.

Hertzman, Marc. (2013), Making samba: A new history of race and music in Brazil. Durham, Duke University Press.

Lenzi, Isabella. (2018), Museu da Imagem e do Som de São Paulo: o processo de criação e as diretrizes iniciais (1970-1980). São Paulo, dissertação de mestrado, Museu de Arqueologia e Etnologia da Universidade de São Paulo.

Maio, Marcos Chor. (out. 1999), "O Projeto Unesco e a agenda das ciências sociais no Brasil dos anos 40 e 50”. Revista Brasileira de Ciências Sociais, [online.], 41 (14): 141-158.

MARCHEZIN, Lucas Tadeu. (2016), Um samba nas quebradas do mundaréu: a história do samba paulistano na voz de Geraldo Filme, Zeca da Casa Verde, Toniquinho Batuqueiro e Plinio Marcos. São Paulo, dissertação de mestrado, IEB-USP.

MendonçA, Tânia. (2012), Museus da Imagem e do Som: o desafio do processo de musealização dos acervos audiovisuais no Brasil. Lisboa, tese de doutorado, Departamento de Museologia da Universidade Lusófona de Humanidades e Tecnologia.

“Metrô anuncia projeto definitivo”. (1978), O Estado de S. Paulo, 01/08, p. 50.

Moraes, José Geraldo Vinci de. (1997), As sonoridades paulistanas a música popular na cidade de São Paulo, final do século XIX ao início do século XX. Rio de Janeiro, São Paulo, Ministério da Cultura, Funarte, Editora Bienal.

NAzaré, José Narciso de. (1981), Entrevista de Sr. Zézinho (José Inácio de Nazaré) e Sebastiana de Oliveira (partes 1 a 4). [Concedida a Olga Von Simson]. Audiovisual. In: Coleção Carnaval Paulistano. São Paulo, Cemis, http://acervo.mis-sp.org.br/, consultado em 10/11/2020. 
“Os Problemas da Zona Oeste”. (1974), O Estado de S. Paulo, 12/11, p. 28.

Paterniani, Stella. (2019) São Paulo cidade negra: branquidade e afrofuturismo a partir de lutas por moradia. 342 p. Brasília, tese de doutorado, Instituto de Ciências Sociais da Universidade de Brasília.

Pereira, João Baptista B. (2001), Cor, profissão e mobilidade o negro e o rádio de São Paulo. São Paulo, Edusp.

Pinto, Maria Inez M. B. (1994), Cotidiano e sobrevivência: a vida do trabalhador pobre na cidade de São Paulo, 1890-1914. São Paulo, Edusp.

Pinto, Regina Pahim. (2013), O Movimento Negro em São Paulo: luta e identidade. Ponta Grossa, São Paulo, Uegp/FCC.

Rolnik, Raquel. (2003), A cidade e a lei: legislação, politica urbana e territórios na cidade de São Paulo. São Paulo, Studio Nobel.

Rolnik, Raquel. ([1989] 2007), “Territórios Negros nas cidades brasileiras: etnicidade e cidade em São Paulo e no Rio de Janeiro". In: Santos, Renato Emerson dos. Diversidade, espaço e relações étnico-raciais: o negro na geografia do Brasil. São Paulo, Autêntica, pp. 75-90.

"SÃo Paulo: um ritmo diferente". (fev. 1972), Realidade, 71: 52-56.

SARA Brasil (1930). Mapa topográfico do município de São Paulo. http://geosampa.prefeitura. sp.gov.br/, consultado em 10/01/2020

Scott, Joan. (fev. 1998), “A invisibilidade da experiência”. Projeto História, (16): 297-325.

Silva, José Carlos Gomes da. (1990), Os sub urbanos e a outra face da cidade. Negros em São Paulo 1900-1930. Cotidiano, lazer e cidadania. Campinas, dissertação de mestrado, Instituto de Filosofia e Ciências Humanas da Universidade Estadual de Campinas.

Silva, Marcos Virgílio da. (2011), Debaixo do "pogréssio": urbanização, cultura e experiência popular em João Rubinato e outros sambistas paulistanos (1951-1969). São Paulo, tese de doutorado, Faculdade de Arquitetura da Universidade de São Paulo.

Silva, Marcos Virgílio da. (2018), A cidade de São Paulo de acordo com Robert Moses e Geraldo Filme. Apresentação de trabalho. Barcelona, Latin American Studies Association.

SimôEs, Nataly. (2020). "Placa em homenagem ao samba é inaugurada no antigo Largo da Banana”. Disponível em https://almapreta.com/editorias/realidade/placa-em-homenagem-ao-samba-e-inaugurada-no-antigo-largo-da-banana, consultado em 21/11/2020.

Simson, Olga Von. (2007), Carnaval em branco e negro (1914-1988). Campinas, Editora da Unicamp/Edusp/Imprensa Oficial.

Simson, Olga Von. (2016), “Unicamp: Memória Científica”. https://www.youtube.com/ watch?v= c TK0kB6IL4M, consultado em 20/08/2021.

SODRÉ, Muniz. (1988), O terreiro e a cidade: a forma social negro-brasileira. Rio de Janeiro, Vozes. Souza, Geraldo Filme. (1968), "Último sambista”. In: Demônios Da Garoa. Leva Este. São Paulo, Chantecler, Faixa 12, https://www.youtube.com/watch?v=Qv_jiQewu0o, consultado em 04/05/2020 
Souza, Geraldo Filme. (1971), “Terreiro da Escola”. In: BArros, Plínio Marcos de et al. Balbina de Iansã - trilha sonora da peça teatral. São Paulo, Fermata, Faixa 19, https://www.youtube. com/watch?v=2qMZ9W_91hU, consultado em 04/05/2020.

\section{Resumo}

Lutas negras no largo da Banana

O largo da Banana, associado aos primórdios do samba paulistano, é tido por território negro de resistência pretérita e antinômica à "modernidade". Cotejando essa construção simbólica com documentos que lhe deram base, sugiro que ele abrigou lutas negras heterogêneas e posteriores à origem do samba. Inquiro expectativas de raça, classe e cultura que informaram a produção de um acervo do MIS-SP e estudos que o mobilizaram a partir dos anos 1970, enredados nos debates sobre autenticidade, cultura negra e relações raciais. Analiso o discurso dos carnavalescos sobre o "berço" do samba à luz de ambições profissionais, por prestígio e respeitabilidade, laterais aos interesses dos pesquisadores, mas centrais para como eles significavam sua história.

Palavras-chave: Largo da Banana; Território negro; Coleção Carnaval Paulistano (MIS-SP); Relações raciais em São Paulo.

\section{Abstract}

\section{Black struggles in largo da Banana}

In São Paulo's early samba accounts, largo da Banana stands for a bygone and non-modern black territory of resistance. By confronting such symbolic construction with sources that validated it, I argue that it was a place of less unidimensional struggles, long after the origin of samba. I inquire race, class, and culture premises entangled in debates about authenticity, black culture, and race relations in MIS-Sp's archive and scholarly studies. I analyze musicians' discourses on the "cradle" of samba, considering professional ambitions and investments on prestige and respectability that, although countered the researchers' expectations, were crucial to the meanings those black men gave to their history.

Keywords: Largo da Banana; Black territory; Coleção Carnaval Paulistano (MIS-SP); Race relations in São Paulo.

Texto recebido em 10/12/2020 e aprovado em 15/06/2021.

DOI: $10.11606 / 0103-2070 . t s .2021 .179762$

Renata Monteiro Siqueira é doutoranda em História e Fundamentos da Arquitetura e do Urbanismo pela Faculdade de Arquitetura e Urbanismo da Universidade de São Paulo. E-mail: renata.fau57@gmail.com. 